\title{
生薬中の微生物分布と放射線殺菌効果
}

\author{
伊藤 均, 鎌倉浩之*，関田節子* \\ 日本原子力研究所高崎研究所 \\ （テ370-1292 群馬県高崎市綿貫町1233） \\ *国立医薬品食品衛生研究所 \\ （テ158-8501 東京都世田谷区上用賀1-18-1）
}

\section{Distribution of Microorganisms in Herb Medicines and Their Decontamination by Gamma-irradiation}

\author{
Hitoshi Ito, Hiroyuki Kamakura * and Setuko Sekita * \\ Takasaki Radiation Chemistry Research Establishment, Japan Atomic Energy Research Institute, \\ Takasaki, Gunma 370-1292, Japan \\ * National Institute of Health Sciences, 1-18-1 Kamiyoga, Tokyo 158-8501, Japan
}

\begin{abstract}
Summary
Herb medicines are traditional medicine in Japan and have been used for medical treatment. These herb medicines are contaminating frequently by microorganisms which has possibility to cause opportunistic diseases. Recently, hygienic standard of herb medicines become more strict than before, and it needs to decontaminate microorganisms by some treatments. However, chemical treatments such as by ethylene oxide fumigation leave toxic residues in the herbs while steam sterilization decrease medicinal components. From study on the distribution of microorganisms in 31 samples of selected herb medicines, colony forming units of total aerobic bacteria were determined to be $1.9 \times 10^{2}$ to $1.4 \times 10^{8}$ per gram in 30 samples. Coliforms were also determined to be $6.9 \times 10^{2}$ to $4.3 \times 10^{6}$ per gram in 16 samples. The main aerobic bacteria were identified as Bacillus pumilus, $B$. circulans, B. megaterium, Erwinia, Enterobacter and Acinetobacter, whereas consisted mainly of Enterobacter in coliform counts. Molds were determined to be $6.3 \times 10^{1}$ to $1.9 \times 10^{5}$ per gram which consisted mainly Aspergillus glaucus group, A. restrictus group, A. flavus group, A. ostianus, A. phoenicis, Penicillium, Tricoderma, Rhizopus and Alternaria in 25 samples. A study on the inactivation of microorganisms at sample No. S18 showed that a gamma-irradiation dose of $20 \mathrm{kGy}$ was required to reduce the total aerobic bacteria and the coliforms below a detectable level, while radiation-resistant bacteria were survived at high doses more than $10 \mathrm{kGy}$ consisted with Acinetobacter and Enterobacter. Molds were inactivated below $8 \mathrm{kGy}$ except Alternaria. However, a dose of $10 \mathrm{kGy}$ should be effective for the sample No. S18 to reduce the spore-forming bacteria, the fecal coliforms and the molds below a detectable level per gram. On the study of inactivation of microorganisms in many samples except the No. 18 , all kinds of microorganism were inactivated below a detectable level at $10 \mathrm{kGy}$ irradiation.
\end{abstract}

\section{緒言}

植物等から得られる生薬には微生物污染の著しい ものが多く，日和見感染の原因になることも考えら
れる。また，生薬によっては収穫後の貯蔵・流通中 に糸状菌が増殖してマイコトキシン産生による污染 の可能性もある。生薬は自然界からの産物のため, 収穫前から様々な微生物が共生または付着してお 
り，たとえ，良好な衛生条件下で収穫・貯蔵しても 微生物の污染は防止できない。近年, 生薬等の衛生 規準がきびしくなってきており，なんらかの殺菌処 理が必要になってきている。しかし, 生薬を酸化工 チレン等の薬剤で処理すれば毒性物質の残留が問題 になるし，蒸気殺菌の場合には薬効成分の低減が問 題になる。香辛料の場合には污染微生物は $7 \sim 10 \mathrm{kGy}$ で殺菌され系状菌の増殖も防止でき, 精油成分や抗 菌性, 抗酸化性もほとんど変化しない ${ }^{1 \sim 5)}$ 。植物由来 の生薬も香辛料と成分的に類似しているため, 照射 による成分変化は少ないと思われるが，放射線殺菌 効果についてはほとんど検討されていない。

本研究では植物由来の生薬について微生物污染の 実態と放射線殺菌効果について検討した。

\section{実験方法}

植物由来の生薬 31 試料（Table1，2）：ケイヒ（試 料 No. ; S1），マオウ（S5）, シャクヤク（S6, S13）, ウイキョウ（S7）カゴソウ (S8), ダイオウ (S9, S11, $\mathrm{S} 12)$, シュクシャ (S15), カンゾウ (S13, S16, K1, $\mathrm{K} 2, \mathrm{~K} 3, \mathrm{~K} 4)$, ショウマ (S18, S28), シャゼンソウ (S19)，インチコウ (S21), ソョウ (S22)，ケイガ 1(S23), センナ (Se1, Se2, Se3, Se4, Se5, Se6, Se7, Se8) を生薬会社より入手し, 一般好気性細菌, 大腸菌群, 一般糸状菌, 好浸透圧性系状菌の污染菌数を香辛料 と同じ方法”で調べた。一般細菌と大腸菌群の代表 的分離株の同定は Bergey's Manual of Systematic Bacteriology, Vol. I ， II (1987)に従って行い, 系状 菌類については The genus Aspergillus ${ }^{7}$ 及び Illustrated genera of Imperfect Fungi ${ }^{8}$ を参考にした。放射線殺菌 効果”は当研究所の約 10 万キュリーのコバルト -60 ガンマ線源を用い, 吸収線量は Fricke 線量計により 測定した。

\section{実験結果}

\section{1. 生薬中の微生物分布}

生薬中の好気性細菌数は Table 1 及び Table 2 に示 すように 1 試料を除いて, $1 \mathrm{~g}$ 中 $1.9 \times 10^{2} \sim 1.4 \times 10^{8}$ 個検出された。大腸菌群は 16 試料より $1 \mathrm{~g}$ 当たり 6.9 x $10^{2} \sim 4.3 \times 10^{6}$ 個検出された。試料 S 11 のダイオウ については菌が全く検出されず，すでになんらかの 殺菌処理が行われているものと思われる。生薬中の 好気性細菌の約 $50 \%$ はBacillus 属で構成されており,
B. pumilus, B. circulans, B. megaterium 等が多く検出 された。また, Erwinia や Enterobacter, Acinetobacter も多く検出された。一方, 大腸菌群の多くは土壤由 来と思われる Enterobacter であり，E. agglomerans や E. cloacae, E. intermedium が検出され, 腸内由来と 思われるCitrobacter も若干検出された。

一般系状菌は 25 試料より $1 \mathrm{~g}$ 当たり $6.3 \times 10^{1} \sim 1.5$ x $10^{5}$ 個検出され，主な系状菌はAspergillus flavus， A. flavus var. columnaris, A. ostianus, A. phoenicis で あり, Penicillium や Tricoderma, Alternaria も検出さ れた。好浸透圧性系状菌は $1 \mathrm{~g}$ 当たり $6.3 \times 10^{1} \sim 1.9$ x $10^{5}$ 個検出され, Aspergillus glaucus 群と A. restrictus 群で構成されていた。好浸透圧性系状菌は低水分活 性下でも増殖可能であり, 試料 S 15 のシュクシャや S22 のソヨウ, Se5 のセンナは糸状菌の増殖が起こっ ていると思われる。また,一般糸状菌数が多いS8の カゴソウや S15 のシュクシャでは A. flavus 群の増殖 初期の状態を示していると思われる。

\section{2. 生薬の放射線殺菌効果}

生薬 30 試料中, 微生物污染が最も著しいS18の ショウマについて殺菌効果を調べたところ,Fig. 1 に 示すように好気性細菌及び大腸菌群は $15 \mathrm{kGy}$ でも多 くの生残菌が認められた。この場合, $10 \mathrm{kGy}$ 以上の 高線量で生残している菌は Acinetobacter と Enterobacter であった。一方, 系状菌類は全て $8 \mathrm{kGy}$ 以下で殺菌 された。S17のカンゾウやK3のカンゾウの場合には, Fig. 2 及びFig. 3に示すように $10 \mathrm{kGy}$ でほぼ殺菌され た。しかし，各試料とも大腸菌群は系状菌に比べ放 射線耐性を示していた。なお，生薬中のBacillus 属 も $10 \mathrm{kGy}$ 以下で検出できなくなった。

そこで, 生薬からの Enterobacter 分離株である $E$. agglomerans K3-1 と E. cloacae K3-2について 0.067M 燐 酸緩衝液中での放射線感受性を比較したところ, $D_{10}$ 値は K3-1 株で $0.25 \mathrm{kGy}, \mathrm{K} 3-2$ 株で $0.35 \mathrm{kGy}$ となり， Citrobacter 分離株の $\mathrm{D}_{10}$ 值 $0.07 \mathrm{kGy}$ または比較に用い た Escherichia coli $\mathrm{S} 2$ 株 の $\mathrm{D}_{10}$ 值 $0.12 \mathrm{kGy}$ の 2 5 倍 あった。さらに，E. agglomerans K3-1 株の定常期細 胞をカンゾウ, ショウマ, センナ粉末中で凍結乾燥 して殺菌効果を調べたところ,Fig. 4 に示すようにカ ンゾウ, ショウマ中ではセンナに比べ放射線に耐性 であった。従って, 生薬によっては高線量でも大腸 菌群が生残する原因は大腸菌群が Enterobacter で主 に構成されており Escherichia coli 等の翼便系大腸菌 
群に比べ放射線に著しく耐性であること及び乾燥生 薬中の放射線保護物質の存在によって説明可能であ る。

\section{考察}

生薬の放射線殺菌で特に問題になる污染微生物は マイコトキシン産生の可能性がある系状菌類と衛生 上問題になる大腸菌群であろう9。Aspergillus 属や Penicillium 属の系状菌はポリエチレン密封下の生薬 でも増殖可能であり ${ }^{11}, 5 \mathrm{kGy}$ 以下の線量で增殖を防 止できると思われる。本研究で分離された A. flavus やA. flavus var. columnaris, A. ostianus はマイコトキ シン産生の可能性があり，放射線殺菌によりこれら の菌の增殖抑制が可能である。なお, 生薬中には $A$. niger 群に属する A. phoenicis と類似したコロニーを 形成する Altenaria 等の不完全菌が検出されること があるが，本菌は放射線に耐性であり $10 \mathrm{kGy}$ 以上で も生残する可能性がある ${ }^{10)}$ 。しかし, 不完全菌の多 くは収穫前からの污染菌であり, 乾燥下での增殖は 考えられない。

生薬の一般細菌及び大腸菌群の殺菌線量は香辛 料 ${ }^{1)}$ に比べ大きい傾向が認められ, 以前の予備的検 討でも必要殺菌線量が $15 \mathrm{kG}$ 以上を越えることが あった。香辛料の場合には構成菌が主にBacillus 属で 占められており, $10 \mathrm{kGy}$ 以下の線量で衛生規準まで 殺菌することが可能であった。一方, 生薬の場合に は Acinetobacter や大腸菌群が $15 \mathrm{kGy}$ でも生残してい ることがある。しかし, 高線量で生残している大腸 菌群は Enterobacter であり，E. coliや Salmonella が高 線量で生残する可能性は考えられない。事実, 伊藤 等が報告したように乾燥魚粉中で Salmonella や E. coli は $5 \mathrm{kGy}$ でほぼ殺菌される ${ }^{11} 。$ また, ブドウ球菌 や緑膿菌等の多くの非芽胞形成細菌の放射線感受性 も Salmonella と同じであり低線量で殺菌可能であ る ${ }^{12 !}$ 。Enterobacter は放射線に耐性であるが, 衛生上 は特に問題のない菌であり, 高線量で生残しても問 題にならないであろう。また, Acinetobacter も衛生 上の問題がない菌である。従って, 生薬の殺菌線量 を $10 \mathrm{kGy}$ としても衛生的に問題がないと思われる が, 簡易的な微生物検查で高線量照射後に大腸菌群 が生残していることは問題であろう。Fig. 1のよう

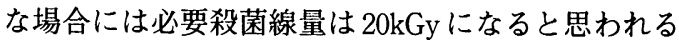
が，粪便系大腸菌群検査により大腸菌群が $1 \mathrm{~g}$ 当た
り 0 個以下，好気性細菌数が $10^{3}$ 個以下とする場合 には必要殺菌線量は $15 \mathrm{kGy}$ となるであろう。また, Bacillus 属等の有芽胞細菌と系状菌, 翼便系大腸菌群 を衛生的な検査対象にすれば殺菌線量は $10 \mathrm{kGy} て ゙ 十$ 分と思われる。

生薬の放射線殺菌を実用化する場合には薬効成分 の変化についても検討しておく必要がある。しかし， 香辛料のように生薬と成分組成が類似している食品 類では精油等の成分変化はほとんど低下せず ${ }^{225)}$,生 薬での研究例でも薬効成分の低減は無視することが できると思われる ${ }^{13)}$ 。

\section{文献}

1 ) Muhamed L. J., H. Ito, H. Watanabe and T. Tamura : Agric. Biol. Chem., 50, 347 (1986).

2 ）渡辺 宏, S. Bagiawati, 田村直幸: 食品照射, 20, 27(1985).

3 ）金子信忠, 伊藤 均, 石垣 功:日食工誌, $\mathbf{3 8}$, 1025 (1991).

4) H. Ito and M. S. Islam : Radiat. Biol. Chem., 43(6), 595 (1994).

5 ) 伊藤 均, Gao Meixu：食品照射, 29, 1(1994).

6 ) J. G. Holt, et al (Ed.) : Bergey's Manual of Systematic Bacteriology, Vol. I and II , Baltimore, Williams and Wilkins, 1986.

7 ) K. B. Raper and D. I. Fennell : The genus Aspergillus, Baltimore, Williams and Wilkins, 1965.

8 ) H. L. Barnett : Illustrated genera of Imperfect Fungi, Minneapolis, Burgess Publishing Company, 1965.

9 ）倉田 浩, 石関忠一, 宇田川俊一: 衛生試験所 報告, 96，1(1978).

10) 伊藤 均, 大木由美, 石垣 功: 防菌防徽, 19, 577(1991).

11）伊藤 均, A. Begum, 久米民和, 武久正昭：農 化, 57, 9(1983).

12）伊藤 均：食品照射， 33，51(1998).

13）木村提二郎, 佐々木将博, 近藤裕一, 城 尚信, 神岡俊隆, 小出祐章: RADIOISOTOPES, 30, 669(1981).

(1999 年 5 月 30 日受理) 
Table 1. Distribution of microorganisms in different samples of herb medicine (colony forming units per gram).

\begin{tabular}{|c|c|c|c|c|}
\hline Sample No. & $\begin{array}{c}\text { Total aerobic } \\
\text { bacteria }\end{array}$ & Coliforms & Fungi & $\begin{array}{l}\text { Osmophilic } \\
\text { molds }\end{array}$ \\
\hline $\begin{array}{l}\text { S1 Cinnamomum } \\
\text { cassia }\end{array}$ & $.25 \times 10^{3}$ & - & - & $1.25 \times 10^{2}$ \\
\hline S5 Ephedra sinica & $5.19 \times 10^{3}$ & - & $2.50 \times 10^{2}$ & $6.25 \times 10^{1}$ \\
\hline $\begin{array}{l}\text { S6 Paeonia } \\
\text { lactiflora }\end{array}$ & $1.88 \times 10^{2}$ & - & - & $1.25 \times 10^{2}$ \\
\hline $\begin{array}{l}\mathrm{S} 7 \text { Foeniculum } \\
\text { vulgare }\end{array}$ & $7.13 \times 10^{5}$ & $6.63 \times 10^{5}$ & $6.88 \times 10^{2}$ & $4.38 \times 10^{2}$ \\
\hline 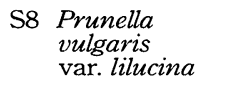 & $2.79 \times 10^{6}$ & $7.08 \times 10^{4}$ & $2.16 \times 10^{4}$ & $7.08 \times 10^{4}$ \\
\hline $\begin{array}{l}\text { S9 Rheum } \\
\text { palmatum }\end{array}$ & $1.34 \times 10^{4}$ & - & $4.17 \times 10^{4}$ & $1.03 \times 10^{4}$ \\
\hline $\begin{array}{l}\text { S10 Foeniculum } \\
\text { vulgare }\end{array}$ & $1.94 \times 10^{4}$ & $1.38 \times 10^{4}$ & $6.50 \times 10^{3}$ & $4.04 \times 10^{3}$ \\
\hline $\begin{array}{l}\mathrm{S} 11 \text { Rheum } \\
\text { palmatum }\end{array}$ & 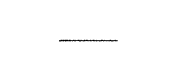 & - & - & - \\
\hline $\begin{array}{l}\text { S12 Rheum } \\
\text { palmatum }\end{array}$ & $1.31 \times 10^{3}$ & - & $7.50 \times 10^{2}$ & $1.01 \times 10^{4}$ \\
\hline $\begin{array}{l}\text { S13 Paeonia } \\
\text { lactiflora }\end{array}$ & $9.38 \times 10^{2}$ & - & $6.25 \times 10^{1}$ & - \\
\hline $\begin{array}{l}\text { S15 Amomum } \\
\text { xanthioides }\end{array}$ & $8.75 \times 10^{6}$ & - & $9.58 \times 10^{4}$ & $1.85 \times 10^{5}$ \\
\hline $\begin{array}{c}\text { S16 Glycyrrhiza } \\
\text { uralensis }\end{array}$ & $1.64 \times 10^{4}$ & $1.50 \times 10^{3}$ & $1.25 \times 10^{2}$ & - \\
\hline $\begin{array}{c}\text { S17 Glycyrrhiza } \\
\text { uralensis }\end{array}$ & $2.13 \times 10^{5}$ & $1.64 \times 10^{4}$ & $3.13 \times 10^{2}$ & $3.13 \times 10^{3}$ \\
\hline $\begin{array}{l}\text { S18 Cimicifuga } \\
\text { simplex }\end{array}$ & $1.38 \times 10^{8}$ & $4.25 \times 10^{6}$ & $2.08 \times 10^{4}$ & $1.06 \times 10^{4}$ \\
\hline $\begin{array}{l}\text { S19 Plantago } \\
\text { asiatica }\end{array}$ & $6.25 \times 10^{4}$ & - & - & $2.20 \times 10^{4}$ \\
\hline $\begin{array}{l}\text { S20 Cimicifuga } \\
\text { simplex }\end{array}$ & $2.59 \times 10^{6}$ & $6.88 \times 10^{2}$ & $6.30 \times 10^{1}$ & - \\
\hline $\begin{array}{l}\text { S21 Artemisia } \\
\text { capillaris }\end{array}$ & $2.53 \times 10^{6}$ & $3.79 \times 10^{5}$ & $3.75 \times 10^{2}$ & $8.75 \times 10^{2}$ \\
\hline $\begin{array}{l}\text { S22 Perilla } \\
\quad \text { frutescens }\end{array}$ & $1.79 \times 10^{6}$ & $3.38 \times 10^{3}$ & $1.44 \times 10^{3}$ & $1.25 \times 10^{5}$ \\
\hline $\begin{array}{c}\text { S23 Schizohepeta } \\
\text { tenuifolia }\end{array}$ & $2.99 \times 10^{4}$ & - & $6.30 \times 10^{1}$ & $1.13 \times 10^{3}$ \\
\hline
\end{tabular}

$*-$ : below detection level 
Table 2. Distribution of microorganisms in Senna (Se) and Licorice (K). (colony forming units per gram)

\begin{tabular}{ccccc}
\hline Sample No. & $\begin{array}{c}\text { Total aerobic } \\
\text { bacteria }\end{array}$ & Coliforms & Fungi & $\begin{array}{c}\text { Osmophilic } \\
\text { molds }\end{array}$ \\
\hline Se 1 & $8.50 \times 10^{3}$ & - & $1.25 \times 10^{2}$ & - \\
Se 2 & $2.93 \times 10^{4}$ & - & $2.50 \times 10^{2}$ & - \\
Se 3 & $3.36 \times 10^{4}$ & $9.88 \times 10^{3}$ & $4.00 \times 10^{3}$ & $4.88 \times 10^{3}$ \\
Se 4 & $1.85 \times 10^{4}$ & $6.25 \times 10^{2}$ & $3.75 \times 10^{2}$ & $1.38 \times 10^{3}$ \\
Se 5 & $7.50 \times 10^{4}$ & $4.63 \times 10^{3}$ & $1.54 \times 10^{5}$ & $1.17 \times 10^{5}$ \\
Se 6 & $2.71 \times 10^{4}$ & $1.50 \times 10^{3}$ & $7.50 \times 10^{2}$ & $1.25 \times 10^{2}$ \\
Se 7 & $2.38 \times 10^{4}$ & $2.38 \times 10^{3}$ & $3.75 \times 10^{2}$ & $1.25 \times 10^{2}$ \\
Se 8 & $1.15 \times 10^{4}$ & - & $2.50 \times 10^{2}$ & $1.25 \times 10^{2}$ \\
K 1 & $3.03 \times 10^{4}$ & - & - & - \\
K 2 & $8.63 \times 10^{5}$ & $5.78 \times 10^{4}$ & $4.88 \times 10^{3}$ & $4.30 \times 10^{4}$ \\
K 3 & $7.50 \times 10^{5}$ & $3.50 \times 10^{3}$ & $1.25 \times 10^{2}$ & $5.00 \times 10^{3}$ \\
K 4 & $2.80 \times 10^{4}$ & - & - & $5.00 \times 10^{2}$ \\
\hline
\end{tabular}

Senna : Cassia sennae, Licorice : Glycyrrhiza uralensis 


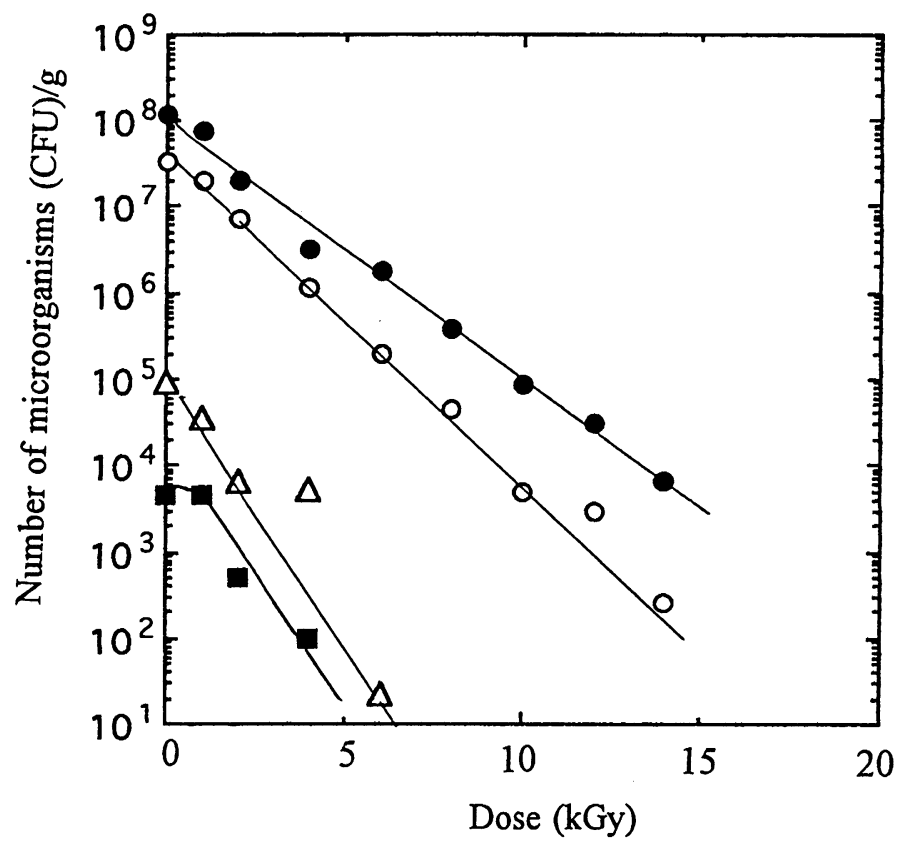

Fig. 1 Inactivation curves for microorganisms in sample No. S18 after gamma-irradiation.

Symbols : $\bigcirc$, total serobic bacteria ; $\bigcirc$, coliform bacteria ; $\boldsymbol{\square}$, fungi ; $\triangle$, osmophilic molds

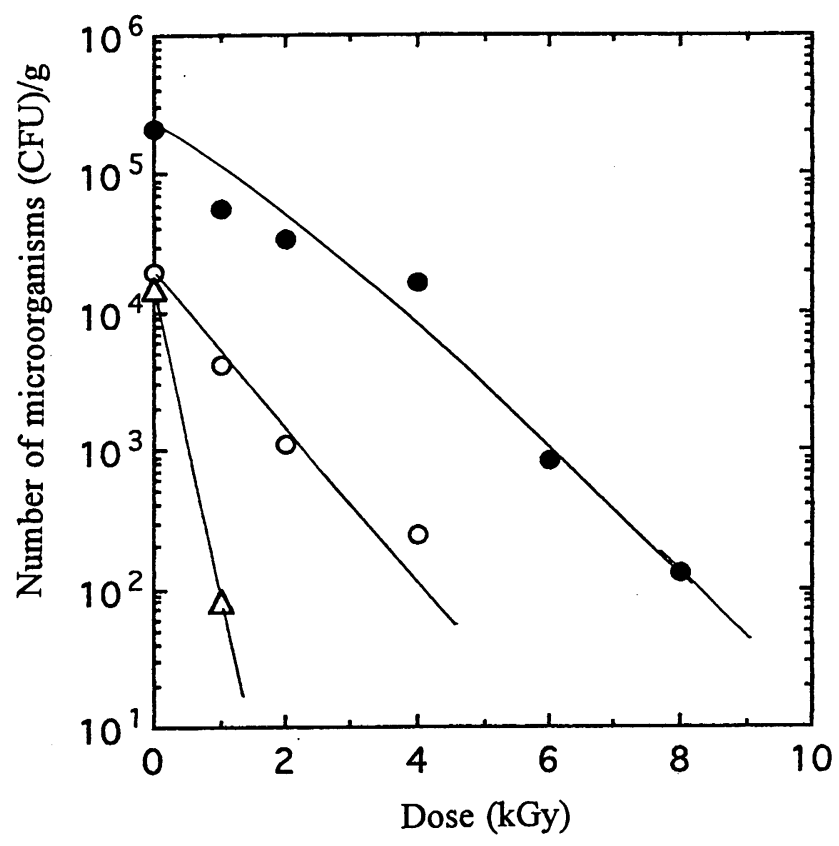

Fig. 2 Inactivation curves for microorganisms in sample No. S17 after gamma-irradiation. Symbols : - total serobic bacteria ; $\bigcirc$, coliform bacteria ; $\Delta$, osmophilic molds 


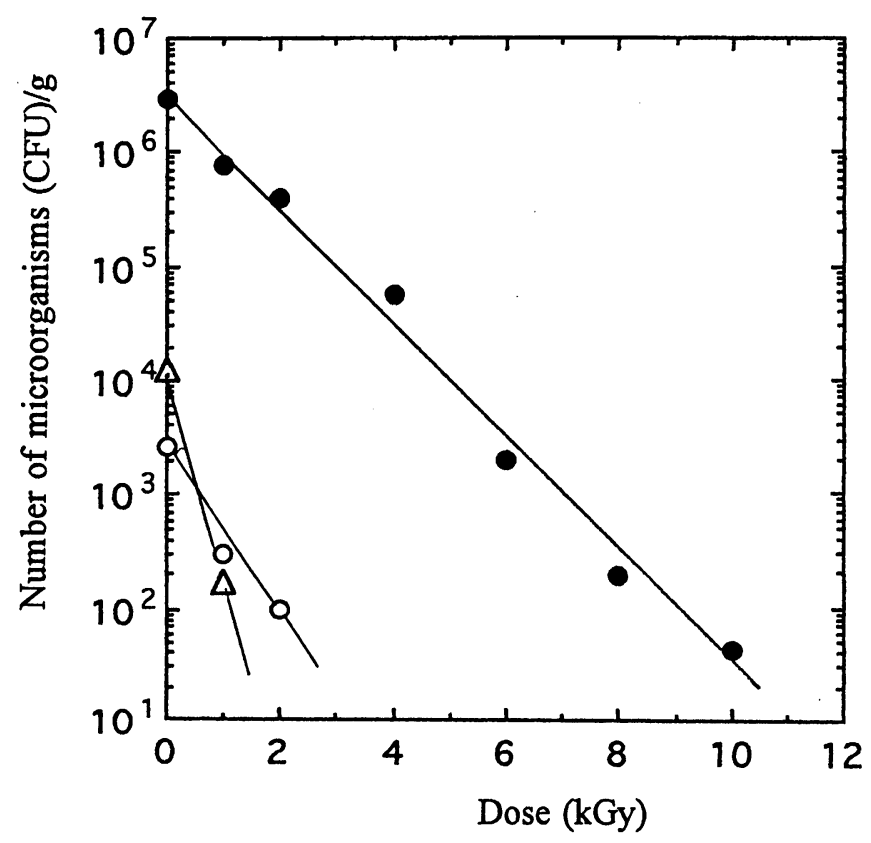

Fig. 3 Inactivation curves for microorganisms in sample No. K3 after gamma-irradiation. Symbols : , total serobic bacteria ; $\bigcirc$, coliform bacteria ; $\triangle$, osmophilic molds

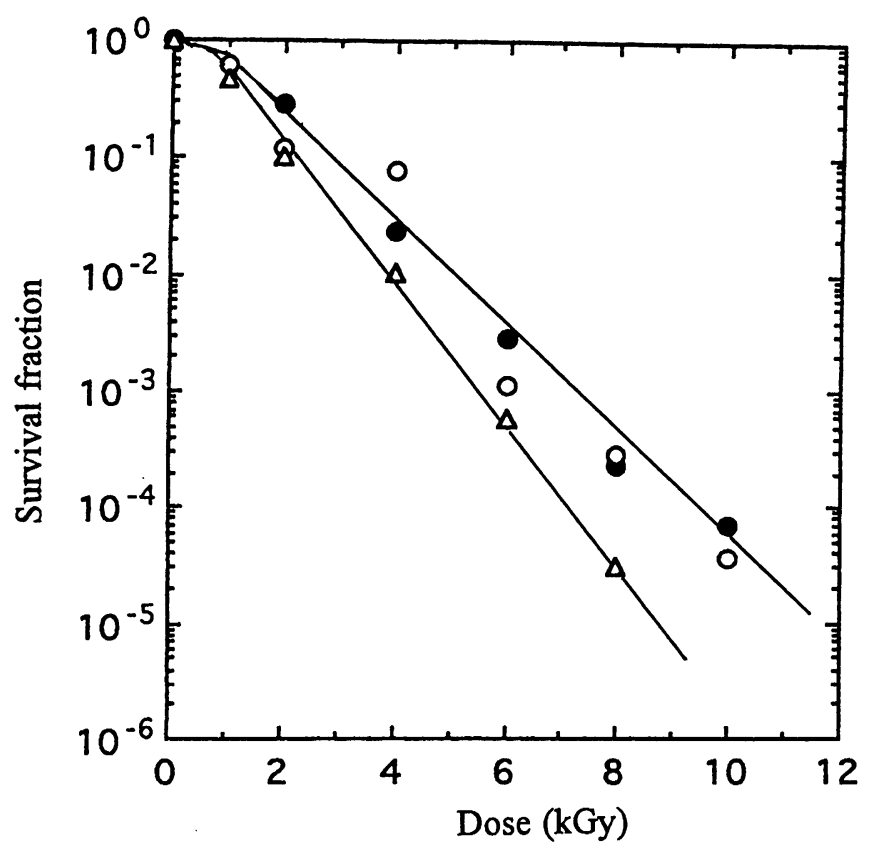

Fig. 4 Survival cuves of Enterbacter agglomerans K3-1 under dried condition in herb medicines after gamma-irradiation.

Symbols : : Sample No. K3, O : Sample No. S18, $\triangle$ : Sample No. Se1 